\title{
Can we predict coronary stenosis localization using regional strain analysis in non-ST elevation acute coronary syndrome?
}

\section{Daniel Lovrić ${ }^{*}$, Marijan Pašalić, Vlatka Rešković Lukšić, \\ Dejan Došen, Kristina Gašparović, Jana Ljubas Maček, Zvonimir Ostojić, Marija Brestovac, Jadranka Šeparović Hanževački}

University of Zagreb School of Medicine, University Hospital Centre Zagreb, Zagreb, Croatia
RECEIVED:

March 11, 2017

ACCEPTED:

April 6, 2017

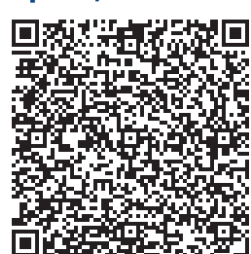

KEYWORDS: regional 2D strain, acute coronary syndrome, coronary stenosis localization. CITATION: Cardiol Croat. 2017;12(4):117-118. | https://doi.org/10.15836/ccar2017.117

*ADDRESS FOR CORRESPONDENCE: Daniel Lovrić, Klinički bolnički centar Zagreb, Kišpatićeva 12, HR-10000 Zagreb, Croatia. / Phone: +385-91-4488-350 / E-mail: daniel@dlovric.net

ORCID: Daniel Lovrić, http://orcid.org/0000-0002-5052-6559 • Marijan Pašalić, http://orcid.org/0000-0002-3197-2190 Vlatka Rešković Lukšić, http://orcid.org/0000-0002-4721-3236 • Dejan Došen, http://orcid.org/0000-0002-2641-4768 Kristina Gašparović, http://orcid.org/0000-0002-1191-4831 • Jana Ljubas Maček, http://orcid.org/0000-0001-7171-2206 Zvonimir Ostojić, http://orcid.org/0000-0003-1762-9270 • Marija Brestovac, http://orcid.org/0000-0003-1542-2890 Jadranka Šeparović Hanževački, http://orcid.org/0000-0002-3437-6407

IIIIIIIIIIIIIIIIIIIIIIIIIIIIIIIIIIIIIIIIIIIIIIIIIIIIIIIIIIIIIIIIIIIIIIIIIIIIIIIIIIIIIIIIIIIIIIIIIIIIIIIIIIIIIIIIIIIIII

Background: It has been shown that 2D strain (2DS) is a sensitive indicator for subclinical myocardial injury due to various agents. However, for detecting coronary artery disease (CAD) global longitudinal 2DS has shown only modest diagnostic accuracy, but the sensitivity of regional 2DS assessment has not been adequately evaluated. ${ }^{1-6}$ The purpose of this study was to assess the value of regional 2DS performed early in patients with non-ST elevation acute coronary syndrome (NSTE-ACS) for predicting presence and localization of ischemia-inducing stenosis, which could then lead the team in further decision-making.

Methods: We performed a retrospective analysis of patients admitted through our Emergency Department to the Department for Cardiovascular Diseases from January 2013 till December 2015 with the diagnosis of NSTE-ACS. Patients who did not undergo coronary angiography, patients with known prior coronary artery disease and patients who did not receive an echo in the 24 hours prior to angiography were excluded, as were the patients with images not adequate for 2D strain analysis. A total of 123 patients fulfilled the criteria and were included in the analysis. 4 different clinicians blinded to laboratory and ECG results performed 2DS analysis of global and regional 2D longitudinal peak systolic strain (LPSS) according to the 18-segment model prior to coronary angiography.

Results: We found significant correlation of a flow limiting stenosis, defined as a stenosis of $>70 \%$ narrowing on coronary angiography, with segmental decrease in LPSS for all three major coronary vessels. Patients with significant left anterior descending artery (LAD) lesion had significantly lower regional LPSS in anterior, septal and anterolateral mid segments and all apical segments (Table 1), as well as global LPSS (-14.43 vs. $-17.22, \mathrm{p}<0.0001)$ when compared to patients without significant stenosis in that vessel.
TABLE 1. Regional 2D longitudinal peak systolic strain values according to segments and location of coronary stenosis.

\begin{tabular}{|c|c|c|c|}
\hline Segment & $\begin{array}{l}\text { Lession } \\
\text { location }\end{array}$ & $\begin{array}{l}\text { LPSS values } \\
\text { (normal vs. pathologic) }\end{array}$ & $\boldsymbol{P}$ \\
\hline Mid anterior & LAD & -15.54 vs. -10.93 & $<0.0001$ \\
\hline Apical anterior & LAD & -20.68 vs. -14.08 & $<0.0001$ \\
\hline Mid anterolateral & LAD & -14.20 vs. -11.38 & 0.003 \\
\hline Apical anterolateral & LAD & -20.35 vs. -14.26 & $<0.0001$ \\
\hline Mid anteroseptal & LAD & -19.55 vs. -15.33 & $<0.0001$ \\
\hline Apical anteroseptal & LAD & -22.89 vs. -16.15 & $<0.0001$ \\
\hline Mid inferoseptal & LAD & -16.28 vs. -13.88 & 0.008 \\
\hline Apical inferoseptal & LAD & -24.00 vs. -17.15 & $<0.0001$ \\
\hline Apical inferior & LAD & -22.67 vs. -18.31 & 0.01 \\
\hline Apical inferolateral & LAD & -19.36 vs. -14.27 & 0.001 \\
\hline Basal anterolateral & LCx & -14.76 vs. -10.92 & 0.001 \\
\hline Mid anterolateral & $\mathrm{LCx}$ & -14.12 vs. -10.96 & 0.003 \\
\hline Basal inferolateral & LCx & -16.28 vs. -12.09 & $<0.0001$ \\
\hline Mid inferolateral & LCx & -15.19 vs. -12.28 & 0.008 \\
\hline Basal inferior & RCA & -16.39 vs. -11.97 & $<0.0001$ \\
\hline Mid inferior & RCA & -16.78 vs. -14.27 & 0.02 \\
\hline Basal inferolateral & RCA & -15.58 vs. -12.56 & 0.01 \\
\hline
\end{tabular}

$L A D=$ left anterior descending coronary artery; $L C x=$ left circumflex coronary artery; RCA = right coronary artery; LPSS - longitudinal peak systolic strain. 


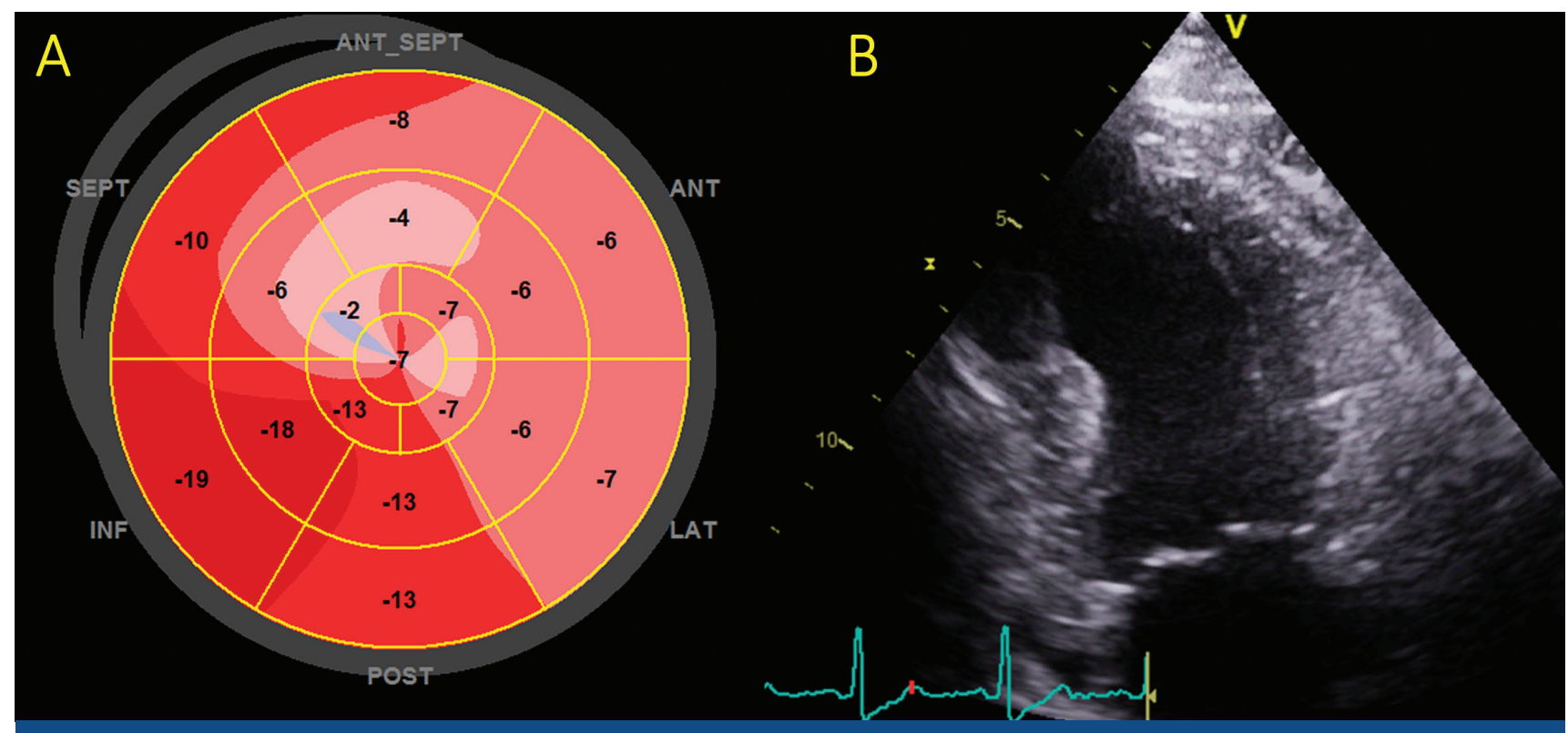

FIGURE 1. Example of significantly reduced regional 2D longitudinal peak systolic strain (A) in a non-ST elevation acute coronary syndrome patient with ostial $95 \%$ significant left anterior descending artery stenosis and preserved anterior wall myocardial thickness (B).

Patients with a significant stenosis in LCx had lower global LPSS in basal and mid anterolateral and inferolateral segments, while patients with a significant RCA stenosis has lower global LPSS in basal and mid inferior and basal inferolateral segments (Figure 1). Statistically significant difference was present in all myocardial layers and was present even after accounting for potentially confounding factors like arterial hypertension, smoking, alcohol, atrial fibrillation, valvular disease, age or prior medical therapy.

Conclusion: We have shown that there is significant correlation between a decrease in LPSS and localization of significant stenosis in patients with NSTE-ACS. The segments with significantly decreased LPSS closely match the areas of perfusion of each coronary vessel. It seems regional 2DS can help define the territory involved in NSTE-ACS and lead further clinical and interventional decision making, but further prospective studies are needed to confirm this assumption.

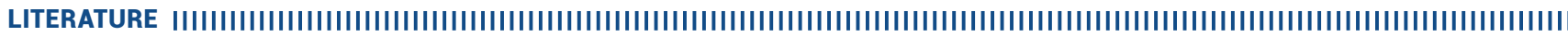

1. Cerqueira MD, Weissman NJ, Dilsizian V, Jacobs AK, Kaul S, Laskey WK, et al; American Heart Association Writing Group on Myocardial Segmentation and Registration for Cardiac Imaging. Standardized myocardial segmentation and nomenclature for tomographic imaging of the heart. A statement for healthcare professionals from the Cardiac Imaging Committee of the Council on Clinical Cardiology of the American Heart Association. Circulation. 2002 Jan 29;105(4):539-42. https://doi.org/10.1161/hc0402.102975

2. Peels $\mathrm{CH}$, Visser $\mathrm{CA}$, Kupper AJ, Visser FC, Roos JP. Usefulness of two-dimensional echocardiography for immediate detection of myocardial ischemia in the emergency room. Am J Cardiol. 1990 Mar 15;65(11):687-91. https://doi.org/10.1016/0002-9149(90)90143-0

3. Sabia P, Afrookteh A, Touchstone DA, Keller MW, Esquivel L, Kaul S. Value of regional wall motion abnormality in the emergency room diagnosis of acute myocardial infarction. A prospective study using two-dimensional echocardiography. Circulation. 1991 Sep;84(3 Suppl):I85-92. https://www.ncbi.nlm.nih.gov/pubmed/1884510

4. Jamal F, Kukulski T, Strotmann J, Szilard M, D'hooge J, Bijnens B, et al; Quantification of the spectrum of changes in regional myocardial function during acute ischemia in closed chest pigs: an ultrasonic strain rate and strain study. J Am Soc Echocardiogr. 2001 Sep;14(9):874-84. https://doi.org/10.1067/mje.2001.112037

5. Montgomery DE, Puthumana JJ, Fox JM, Ogunyankin KO. Global longitudinal strain aids the detection of non-obstructive coronary artery disease in the resting echocardiogram. Eur Heart J Cardiovasc Imaging. 2012 Jul;13(7):579-87. https://doi.org/10.1093/ejechocard/jer282

6. Choi JO, Cho SW, Song YB, Cho SJ, Song BG, Lee SC, et al; Longitudinal 2D strain at rest predicts the presence of left main and three vessel coronary artery disease in patients without regional wall motion abnormality. Eur J Echocardiogr. 2009 Jul;10(5):695-701. https://doi.org/10.1093/ejechocard/jep041 